\title{
Incarcerated abdominal wall hernia surgery: relationship between risk factors and morbidity and mortality rates (a single center emergency surgery experience)
}

\author{
Boğulmuş abdominal duvar herni cerrahisi: Morbidite ve mortalite insidansının risk \\ faktörleriyle ilişkisinin analizi (Tek merkezli acil cerrahi deneyimi)
}

\author{
Erkan ÖZKAN, Mehmet Kamil YILDIZ, Tuğrul ÇAKIR, Ender DULUNDU, Cengiz ERİş, \\ Mehmet Mahir FERSAHOĞLU, Ümit TOPALOĞLU
}

\section{BACKGROUND}

The aim of the present study was to investigate morbidityand mortality-related risk factors in patients undergoing surgery due to incarcerated abdominal wall hernia.

\section{METHODS}

The patients were grouped according to the type of hernia (inguinal, umbilical, incisional, femoral), and these groups were evaluated in terms of risk factors affecting morbidity and mortality such as age, gender, American Society of Anesthesiologists (ASA) score, type of anesthesia, concomitant diseases, and the presences of intestinal strangulation and necrosis.

\section{RESULTS}

Inguinal hernia was frequent in males, whereas femoral hernia was frequent in females $(p<0.001)$. The rate of intestinal resection due to strangulation and necrosis was found significantly higher among femoral hernias as compared to the other types of hernia ( $p<0.005$ and $p<0.001$, respectively). Advanced age ( $\geq 65$ years), concomitant disease, strangulation, necrosis, high ASA score (III-IV), time from the onset of symptoms, and time to hospital admission were found to have significant influences on morbidity and mortality. General anesthesia was found to be a risk factor for morbidity as well $(\mathrm{p}<0.05)$.

\section{CONCLUSION}

Incarcerated abdominal wall hernias are surgical problems with high morbidity and mortality rates. Therefore, surgery should be planned under elective conditions when hernia is detected.

Key Words: Abdominal wall hernia; incarceration; necrosis; strangulation.

\section{AMAÇ}

$\mathrm{Bu}$ çalışmada, acil cerrahi kliniğimizde boğulmuş abdominal duvar hernisi nedeniyle ameliyat edilen hastalarda morbidite ve mortaliteyle ilişkili risk faktörlerinin insidansı araştırıldı.

\section{GEREÇ VE YÖNTEM}

Hastalar hem fitık türüne göre (inguinal, umblikal, insizyonel, femoral) kendi aralarında hem de morbidite ve mortalite üzerine etkili faktörler bakımından; yaş, cinsiyet, Amerikan Anesteziyoloji Derneği (AAD) skoru, anestezi tipi, eşlik eden hastalıklar, intestinal boğulma ve nekroz varlığ gibi verilerle değerlendirildi.

\section{BULGULAR}

İnguinal herni erkeklerde, umblikal ve femoral herni kadinlarda sıktı $(p<0,001)$. Femoral hernide boğulma ve nekrozdan dolayı intestinal rezeksiyon diğer fitık türlerine göre anlamlı olarak yüksek saptandı (sırasıyla, $p<0,005$ ve $p<0,001)$. Morbidite ve mortalite üzerine; ileri yaş $(\geq 65$ yaş), ek hastalık, strangülasyon, nekroz, yüksek AAD skoru (III, IV), semptomların başlama ve hastaneye başvuru süresinin anlamlı etkisi bulundu. Genel anestezinin de morbidite için risk oluşturduğu görüldü $(\mathrm{p}<0,05)$.

\section{SONUÇ}

Boğulmuş abdominal duvar hernileri yüksek morbidite ve mortalite oranına sahip bir cerrahi problemdir. Bu yüzden herni saptandığında elektif koşullarda ameliyat planlanmalidir.

Anahtar Sözcükler: Abdominal duvar hernisi; inkarserasyon; nekroz; strangülasyon. 5. Genel Cerrahi Kliniği, İstanbul. 
Abdominal wall hernia (AWH) surgery is among the most frequently performed general surgical operations throughout the world. ${ }^{[1]}$ Incarceration and strangulation are the most severe complications and account for a substantial portion of the patients presenting to emergency surgery clinics with acute abdominal complaints. Of the AWH cases, approximately 5\%-13\% may require emergency surgery due to incarceration and obstruction, and of the cases undergoing emergency surgery, $10 \%-15 \%$ may require intestinal resection due to necrosis. ${ }^{[2,3]}$ In such surgical operations, inadequate preoperative preparation and the advanced age of the majority of the patients lead to a remarkable increase in morbidity and mortality ${ }^{[4]}$

The aim of the present study was to evaluate the rate of morbidity- and mortality-related risk factors in patients undergoing surgical operation in our emergency surgery clinic due to incarcerated AWH.

\section{MATERIALS AND METHODS}

One hundred and ninety patients underwent emergency surgery due to incarcerated AWH in the 5th General Surgery Clinic of Haydarpasa Training and Research Hospital between December 2003 and January 2011. Indications for emergency surgery included irreducible mass, pain localized to the abdominal wall, and the signs and symptoms of mechanical intestinal obstruction. All patients were systematically evaluated prior to the operation. Complete blood count, biochemical analysis, and electrocardiography (ECG) were performed. Chest and direct abdominal radiographs were obtained while the patient was in a standing position. Those with a concomitant disease were preoperatively referred to the related clinics for consultation according to pathological data and medical histories. A single dose of second-generation cephalosporin was administered as prophylaxis. Cases with intestinal necrosis, which failed to normalize despite hot saline application and waiting after the release of the neck of the hernia sac, required resection and anastomosis. In patients with intestinal necrosis, antibiotherapy was continued in the postoperative period for an additional five days on average. All the patients underwent surgical operation within the first 24 hours of their hospital admission. General anesthesia was preferred for incarcerated umbilical hernia and incisional hernia of the upper abdomen, whereas spinal or general anesthesia was performed for incarcerated inguinal and femoral hernias and incisional hernia of the lower abdomen. The anesthesiologist decided the type of anesthesia to be performed. Inguinal incisions were used for inguinal and femoral hernias. However, the operation was completed by converting the incision into superior and inferior umbilical incision in inguinal and femoral hernia cases undergoing intestinal resection and anastomosis. Cooper's ligament hernioplasty (McWay) and anterior prosthetic meshplug hernioplasty methods were used in femoral hernia cases, whereas tension-free hernia repair was performed with monofilament polypropylene mesh in the other types of hernia. The term morbidity was used for postoperative major and minor complications (wound site, pulmonary and cardiac complications). The term mortality was used for deaths within 30 days of the operation or before discharge from the hospital. The patients were grouped according to the hernia type, and the groups were then evaluated with respect to the factors affecting morbidity and mortality, such as age, gender, American Society of Anesthesiologists (ASA) score, type of anesthesia, intestinal strangulation and necrosis, and the presence of a concomitant disease. Statistical analyses of the data were performed using Number Cruncher Statistical System (NCSS) 2007 and Power Analysis and Sample Size (PASS) 2008 Statistical Software (Utah, USA) program. In addition to the descriptive statistical methods (mean, standard deviation, ratio), Kruskal-Wallis test was used for the intergroup comparison of the quantitative data, whereas Mann-Whitney U-test was used to identify the group that caused the difference and for the comparison of two groups. Qualitative data were compared using chi-square test and Fisher's exact test. A $p$ value $<0.05$ was considered statistically significant.

\section{RESULTS}

Of the 2,380 AWH cases (inguinal, umbilical, incisional, femoral) operated in the 5th General Surgery Clinic of Istanbul Haydarpasa Training and Research Hospital between December 2003 and January 2011, 190 (7.98\%) underwent emergency surgery due to incarceration. Considering the hernia type, the rate of emergency surgery was the highest among femoral hernias $(47.1 \%)$, but the lowest among inguinal hernias $(6.1 \%)$ (Table 1$)$. Of the emergency cases with incarceration, $55.8 \%$ had inguinal, $21.1 \%$ had umbilical, $14.7 \%$ had incisional, and $8.4 \%$ had femoral hernias. The mean age of the cases was 60.81 15.51 (range, $27-92$ years $)$. Of the cases, $64.7 \%(n=123)$ were males and $35.3 \%(n=67)$ were females.

Table 1. The prevalence of emergency surgical procedures according to the hernia type

\begin{tabular}{lcc}
\hline $\begin{array}{l}\text { Type of } \\
\text { hernia }\end{array}$ & $\begin{array}{c}\text { Emergency surgical } \\
\text { procedure } \\
\mathrm{n}(\%)\end{array}$ & $\begin{array}{c}\text { Total surgical } \\
\text { procedures } \\
\mathrm{n}\end{array}$ \\
\hline Inguinal & $106(6.12 \%)$ & 1732 \\
Umbilical & $40(9.95 \%)$ & 402 \\
Incisional & $28(13.2 \%)$ & 212 \\
Femoral & $16(47.05 \%)$ & 34 \\
\hline
\end{tabular}


Table 2. Evaluations according to the hernia types

\begin{tabular}{|c|c|c|c|c|c|}
\hline & \multicolumn{4}{|c|}{ Type of hernia } & \multirow[b]{2}{*}{$p$} \\
\hline & $\begin{array}{l}\text { Inguinal } \\
(n=106)\end{array}$ & $\begin{array}{l}\text { Incisional } \\
(\mathrm{n}=28)\end{array}$ & $\begin{array}{l}\text { Umbilical } \\
(\mathrm{n}=40)\end{array}$ & $\begin{array}{c}\text { Femoral } \\
(n=16)\end{array}$ & \\
\hline \multicolumn{6}{|l|}{ Age } \\
\hline$<65$ & $64(60.4 \%)$ & $12(42.9 \%)$ & $25(62.5 \%)$ & $8(50 \%)$ & \multirow[t]{2}{*}{0.309} \\
\hline$\geq 65$ & $42(39.6 \%)$ & $16(57.1 \%)$ & $15(37.5 \%)$ & $8(50 \%)$ & \\
\hline \multicolumn{6}{|l|}{ Gender } \\
\hline Male & $90(84.9 \%)$ & $16(57.1 \%)$ & $12(30 \%)$ & $5(31.3 \%)$ & \multirow[t]{2}{*}{$0.001 * *$} \\
\hline Female & $16(15.1 \%)$ & $12(42.9 \%)$ & $28(70 \%)$ & $11(68.8 \%)$ & \\
\hline \multicolumn{6}{|c|}{ American Society of Anesthesiologists } \\
\hline I & $6(5.7 \%)$ & $2(7.1 \%)$ & $6(15 \%)$ & $0(0 \%)$ & \multirow[t]{4}{*}{$0.026 *$} \\
\hline II & $42(39.6 \%)$ & $15(53.6 \%)$ & $16(40 \%)$ & $8(50 \%)$ & \\
\hline III & $46(43.4 \%)$ & $3(10.7 \%)$ & $12(30 \%)$ & $4(25 \%)$ & \\
\hline IV & $12(11.3 \%)$ & $8(28.6 \%)$ & $6(15 \%)$ & $4(25 \%)$ & \\
\hline \multicolumn{6}{|l|}{ Anesthesia } \\
\hline General & $58(54.7 \%)$ & $24(85.7 \%)$ & $40(100 \%)$ & $13(81.3 \%)$ & \multirow[t]{2}{*}{$0.001 * *$} \\
\hline Spinal & $48(45.3 \%)$ & $4(14.3 \%)$ & $0(0 \%)$ & $3(18.7 \%)$ & \\
\hline \multicolumn{6}{|c|}{ Intestinal strangulation } \\
\hline Positive & $44(41.5 \%)$ & $16(57.1 \%)$ & $18(45 \%)$ & $14(87.5 \%)$ & \multirow[t]{2}{*}{$0.005 \% *$} \\
\hline Negative & $62(58.5 \%)$ & $12(42.9 \%)$ & $22(55 \%)$ & $2(12.5 \%)$ & \\
\hline \multicolumn{6}{|c|}{ Concomitant disease } \\
\hline Positive & $51(49.2 \%)$ & $12(42.8 \%)$ & $17(42.5 \%)$ & $7(43.7 \%)$ & \multirow[t]{2}{*}{0.913} \\
\hline Negative & $55(51.8 \%)$ & $16(57.2 \%)$ & $23(57.5 \%)$ & $9(56.3 \%)$ & \\
\hline \multicolumn{6}{|c|}{ Intestinal necrosis } \\
\hline Positive & $14(13.2 \%)$ & $7(25 \%)$ & $6(15 \%)$ & $10(62.5 \%)$ & \multirow[t]{2}{*}{$0.001 * *$} \\
\hline Negative & $92(86.8 \%)$ & $21(75 \%)$ & $34(85 \%)$ & $6(37.5 \%)$ & \\
\hline \multicolumn{6}{|l|}{ Morbidity } \\
\hline Positive & $14(13.2 \%)$ & $7(25 \%)$ & $4(10 \%)$ & $2(12.5 \%)$ & \multirow[t]{2}{*}{0.336} \\
\hline Negative & $92(86.8 \%)$ & $21(75 \%)$ & $36(90 \%)$ & $14(87.5 \%)$ & \\
\hline \multicolumn{6}{|l|}{ Mortality } \\
\hline Positive & $5(4.7 \%)$ & $1(3.6 \%)$ & $0(0 \%)$ & $0(0 \%)$ & \multirow[t]{2}{*}{0.443} \\
\hline Negative & $101(95.3 \%)$ & $27(96.4 \%)$ & $40(100 \%)$ & $16(100 \%)$ & \\
\hline \multicolumn{6}{|l|}{ Recurrence } \\
\hline Yes & $6(5.9 \%)$ & $1(3.8 \%)$ & $1(2.5 \%)$ & $0(0 \%)$ & \multirow[t]{2}{*}{0.642} \\
\hline No & $95(94.1 \%)$ & $25(96.2 \%)$ & $39(97.5 \%)$ & $16(100 \%)$ & \\
\hline
\end{tabular}

Chi-square test was used $* \mathrm{p}<0.05 ; * * \mathrm{p}<0.01$.

General anesthesia was preferred in $135(71.0 \%)$ and spinal anesthesia in $55(29.0 \%)$ cases. The rate of using general anesthesia was significantly higher in umbilical and incisional hernia surgeries $(\mathrm{p}<0.001)$.

Hernias were simply reduced in $98(51.5 \%)$ patients; however, strangulation was detected in 92 $(48.5 \%)$ patients during the surgery. Whereas intestinal blood circulation recovered in $55(29 \%)$ patients, $37(19.5 \%)$ patients underwent intestinal resection (33 [17.3\%] small intestine and 4 [2.2\%] colon) and anastomosis due to necrosis. Omental resection was required in $6(3.1 \%)$ patients.

There was a significant difference between genders in terms of hernia types. Inguinal hernia was more common in males, whereas umbilical and femoral hernias were more common in females $(\mathrm{p}<0.001)$ (Fig. 1, Table 2). The rate of intestinal resection due to strangulation and necrosis was found significantly higher in femoral hernias as compared to the other types of hernia $(p<0.005$ and $p<0.001$, respectively) (Table 2 ). There was no significant difference between the types of hernia in terms of age, morbidity, mortality, or recurrence rates $(\mathrm{p}>0.05)$ (Table 2).

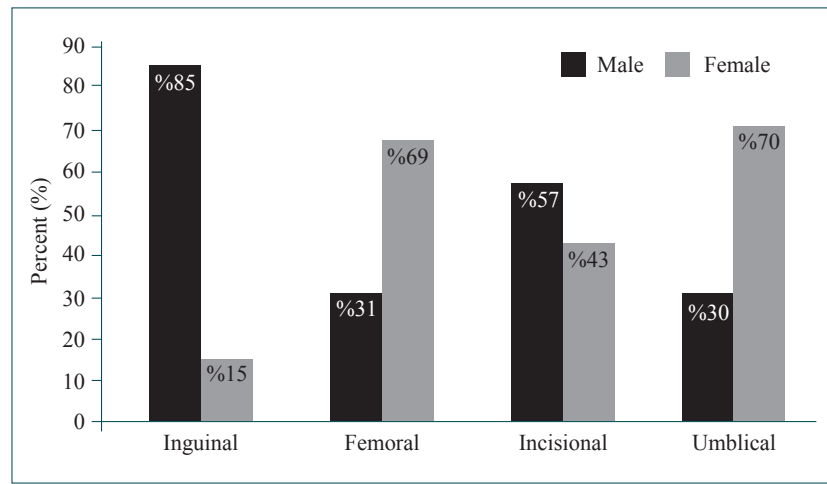

Fig. 1. Distribution of types of hernia according to genders. 
Table 3. Evaluations according to morbidity

\begin{tabular}{|c|c|c|c|}
\hline & Mo & oidity & $p$ \\
\hline & $\begin{array}{c}\text { Positive } \\
\text { n }(\%)\end{array}$ & $\begin{array}{c}\text { Negative } \\
\text { n }(\%)\end{array}$ & \\
\hline Age & & & \\
\hline$<65$ & $4(14.8 \%)$ & $105(64.4 \%)$ & $0.001 * *$ \\
\hline$\geq 65$ & $23(85.2 \%)$ & $58(35.6 \%)$ & \\
\hline Gender & & & \\
\hline Male & $17(63 \%)$ & $106(65 \%)$ & 0.835 \\
\hline Female & $10(37 \%)$ & $57(35 \%)$ & \\
\hline Type of herni & & & \\
\hline Inguinal & $14(51.9 \%)$ & $92(56.4 \%)$ & 0.336 \\
\hline Femoral & $2(7.4 \%)$ & $14(8.6 \%)$ & \\
\hline Incisional & $7(25.9 \%)$ & $21(12.9 \%)$ & \\
\hline Umbilical & $4(14.8 \%)$ & $36(22.1 \%)$ & \\
\hline Concomitant & & & \\
\hline Positive & $21(77.7 \%)$ & $66(40.4 \%)$ & $0.001 * *$ \\
\hline Negative & $6(22.3 \%)$ & $97(59.6 \%)$ & \\
\hline Intestinal stra & & & \\
\hline Positive & $22(81.5 \%)$ & $70(42.9 \%)$ & $0.001 * *$ \\
\hline Negative & $5(18.5 \%)$ & $93(57.1 \%)$ & \\
\hline Symptom dur & & & \\
\hline$\leq 24$ hours & $6(22.2 \%)$ & $114(69.9 \%)$ & $0.001 * *$ \\
\hline$>24$ hours & $21(77.8 \%)$ & $49(30.1 \%)$ & \\
\hline ASA & & & \\
\hline I-II & $2(7.4 \%)$ & $93(57.1 \%)$ & $0.001 * *$ \\
\hline III-IV & $25(92.6 \%)$ & $70(42.9 \%)$ & \\
\hline Intestinal nec & & & \\
\hline Positive & $14(51.9 \%)$ & $23(14.1 \%)$ & $0.001 * *$ \\
\hline Negative & $13(48.1 \%)$ & $140(85.9 \%)$ & \\
\hline Anesthesia & & & \\
\hline General & $25(92.6 \%)$ & $114(69.9 \%)$ & $0.017^{*}$ \\
\hline Spinal & $2(7.4 \%)$ & $49(30.1 \%)$ & \\
\hline
\end{tabular}

ASA: American Society of Anesthesiologists. Chi-square test was used. ${ }^{*} \mathrm{p}<0.05 ; * * \mathrm{p}<0.01$.

Mortality was detected in $6(3.1 \%)$ patients, and the reasons for mortality were congestive cardiac insufficiency in 4, pulmonary embolism in 1, and adult respiratory distress syndrome (respiratory insufficiency) in 1 patient.
Table 4. Evaluations according to mortality

\begin{tabular}{|c|c|c|c|}
\hline & \multicolumn{2}{|c|}{ Mortality } & \multirow[t]{2}{*}{$p$} \\
\hline & $\begin{array}{c}\text { Positive } \\
\text { n }(\%)\end{array}$ & $\begin{array}{c}\text { Negative } \\
\text { n }(\%)\end{array}$ & \\
\hline \multicolumn{4}{|l|}{ Age } \\
\hline$<65$ & $0(0 \%)$ & $109(59.2 \%)$ & \multirow[t]{2}{*}{$0.005 * *$} \\
\hline$\geq 65$ & $6(100 \%)$ & $75(40.8 \%)$ & \\
\hline \multicolumn{4}{|l|}{ Gender } \\
\hline Male & $5(83.3 \%)$ & $118(64.1 \%)$ & \multirow[t]{2}{*}{0.427} \\
\hline Female & $1(16.7 \%)$ & $66(35.9 \%)$ & \\
\hline \multicolumn{4}{|l|}{ Type of hernia } \\
\hline Inguinal & $5(83.3 \%)$ & $101(54.9 \%)$ & \multirow[t]{4}{*}{0.443} \\
\hline Femoral & $0(0 \%)$ & $16(8.7 \%)$ & \\
\hline Incisional & $1(16.7 \%)$ & $27(14.7 \%)$ & \\
\hline Umbilical & $0(0 \%)$ & $40(21.7 \%)$ & \\
\hline \multicolumn{4}{|c|}{ Intestinal strangulation } \\
\hline Positive & $4(66.7 \%)$ & $88(47.8 \%)$ & \multirow[t]{2}{*}{0.433} \\
\hline Negative & $2(33.3 \%)$ & $96(52.2 \%)$ & \\
\hline \multicolumn{4}{|c|}{ Symptom duration } \\
\hline$\leq 24$ hours & $1(16.7 \%)$ & $119(64.7 \%)$ & \multirow[t]{2}{*}{$0.026 *$} \\
\hline$>24$ hours & $5(83.3 \%)$ & $65(35.3 \%)$ & \\
\hline \multicolumn{4}{|c|}{ Concomitant disease } \\
\hline Positive & $6(100 \%)$ & $81(44.0 \%)$ & \multirow[t]{2}{*}{$0.008 * *$} \\
\hline Negative & $0(0 \%)$ & $103(56 \%)$ & \\
\hline \multicolumn{4}{|l|}{ ASA score } \\
\hline I-II & $0(0 \%)$ & $95(51.6 \%)$ & \multirow[t]{2}{*}{$0.029 *$} \\
\hline III-IV & $6(100 \%)$ & $89(48.4 \%)$ & \\
\hline \multicolumn{4}{|c|}{ Intestinal necrosis } \\
\hline Positive & $4(66.7 \%)$ & $33(17.9 \%)$ & \multirow[t]{2}{*}{$0.014 *$} \\
\hline Negative & $2(33.3 \%)$ & $151(82.1 \%)$ & \\
\hline \multicolumn{4}{|l|}{ Anesthesia } \\
\hline General & $5(83.3 \%)$ & $134(72.8 \%)$ & \multirow[t]{2}{*}{1.000} \\
\hline Spinal & $1(16.7 \%)$ & $50(27.2 \%)$ & \\
\hline
\end{tabular}

ASA: American Society of Anesthesiologists. Chi-square test, Fisher's exact test were used. ${ }^{*} \mathrm{p}<0.05 ; * * \mathrm{p}<0.01$.

Morbidity was detected in 27 (14.2\%) patients, and the reasons for morbidity were local wound site complications in 14 (10 wound site infection, 4 seroma), postoperative ileus in 4 , testicular edema in 3 , atelectasis in 2, pneumonia in 2, and congestive cardiac insuffi-

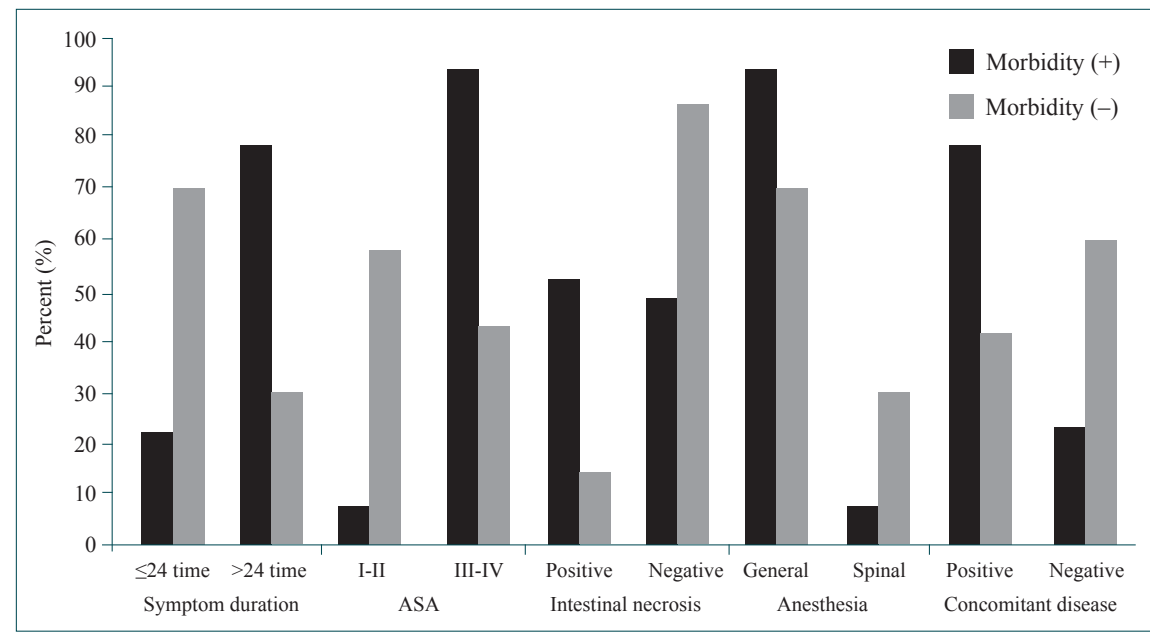

Fig. 2. Factors affecting morbidity. 


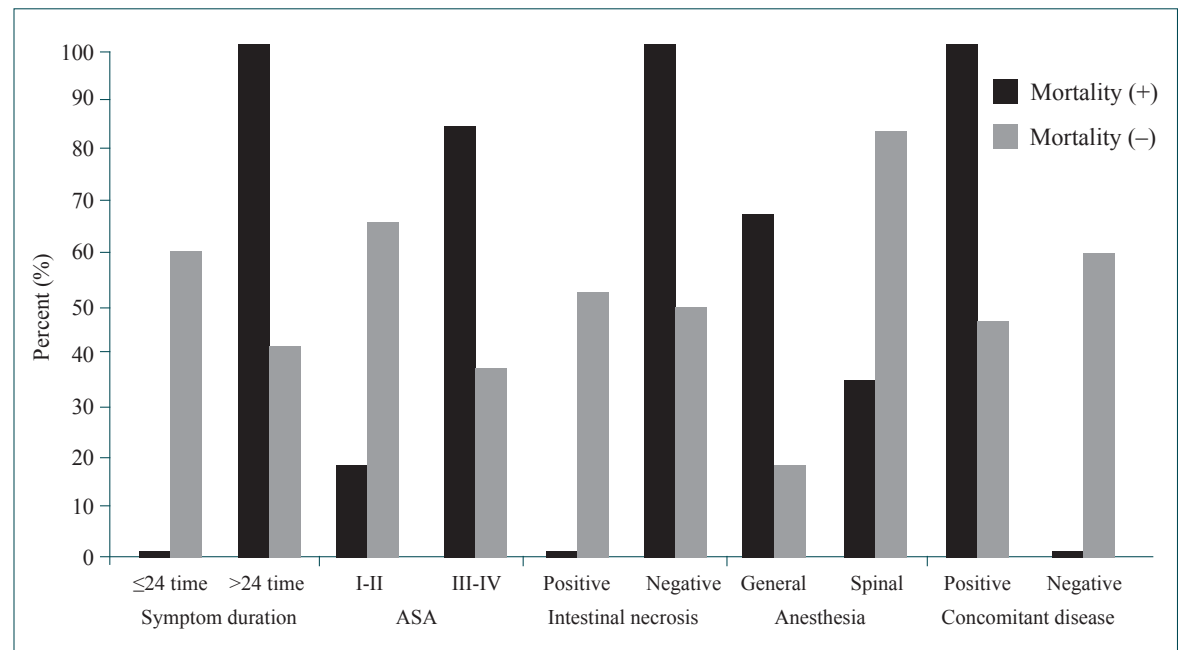

Fig. 3. Factors affecting mortality.

ciency in 2 patients. Concomitant disease was detected in $87(45.7 \%)$ patients. Concomitant diseases included chronic obstructive pulmonary disease (COPD), coronary artery disease, congestive cardiac insufficiency, hypertension, and type 2 diabetes mellitus.

The rates of advanced age ( $\geq 65$ years), strangulation, necrosis, high ASA score (III-IV), symptom duration, and presence of concomitant diseases were found significantly high in the group with morbidity and mortality as compared to the group without morbidity and mortality (Tables 3, 4, Figs. 2, 3). The present study demonstrated that general anesthesia was a risk for morbidity as well $(\mathrm{p}<0.05)$.

There was a significant difference between hernia types in terms of duration of hospital stay $(p<0.01)$. Duration of hospital stay was found significantly shorter in the inguinal hernia group as compared to the femoral, incisional and umbilical hernia groups $(\mathrm{p}<0.003, \mathrm{p}<0.001$ and $\mathrm{p}<0.004$, respectively). No significant difference was found between the femoral, incisional and umbilical hernia groups in terms of duration of hospital stay (Table 5) $(\mathrm{p}>0.05)$. Duration of hospital stay was significantly higher in the cases with necrosis as compared to those without necrosis (Table 6) $(\mathrm{p}<0.001)$.

\section{DISCUSSION}

Despite the advances in anesthesia, antisepsis, antibiotics, and fluid replacement, the morbidity and mortality following incarcerated AWH surgery remain high. The rates of mortality and morbidity have been reported to be approximately $5 \%$ and $20 \%-30 \%$, respectively. ${ }^{[2,4-6]}$ The results obtained in the present study were consistent with the literature showing a mortality rate of $3.1 \%$ and a morbidity rate of $14.2 \%$. Many factors affecting mortality and morbidity have been reported. In the present study, the morbidity rate was the highest in incisional hernia, whereas the mortality rate was the highest in inguinal hernia, and no significant effect of the hernia type was determined $(\mathrm{p}>0.05)$.

While incarcerated inguinal hernias have been more commonly reported in males, femoral and umbilical hernias are more common in females, and no significant effect of gender on mortality and morbidity has been shown..$^{[2,7]}$ Similarly, in the present study, inguinal hernia was more common in males and femoral and umbilical hernias were more common in females

Table 6. Duration of hospital stay according to intestinal necrosis

\begin{tabular}{lccc}
\hline & \multicolumn{2}{c}{ Duration of hospital stay } & $p$ \\
\cline { 2 - 3 } Intestinal necrosis & Mean \pm SD & Median & \\
\hline Positive & $8.78 \pm 6.42$ & 4.0 & $0.001^{* *}$ \\
Negative & $4.63 \pm 2.49$ & 7.0 & \\
\hline
\end{tabular}

Mann-Whitney U test $* * \mathrm{p}<0.01$

Table 5. Evaluation of time of discharge according to the hernia types

\begin{tabular}{|c|c|c|c|c|c|}
\hline & \multicolumn{4}{|c|}{ Type of hernia } & \multirow[b]{2}{*}{$p$} \\
\hline & $\begin{array}{c}\text { Inguinal } \\
\text { Mean } \pm \text { SD (median) }\end{array}$ & $\begin{array}{c}\text { Femoral } \\
\text { Mean } \pm \text { SD (median) }\end{array}$ & $\begin{array}{c}\text { Incisional } \\
\text { Mean } \pm \text { SD (median) }\end{array}$ & $\begin{array}{c}\text { Umbilical } \\
\text { Mean } \pm \text { SD (median) }\end{array}$ & \\
\hline Time of discharge (days) & $4.20 \pm 2.23(4)$ & $7.75 \pm 6.84(5)$ & $6.22 \pm 2.61(6)$ & $6.30 \pm 4.51(5.5)$ & $0.001 * *$ \\
\hline
\end{tabular}


$(\mathrm{p}<0.001)$; no significant effect of gender on morbidity $(\mathrm{p}=0.835)$ or mortality $(\mathrm{p}=0.427)$ was observed.

Advanced age ( $\geq 65$ years) is an effective factor on morbidity and mortality in incarcerated AWH surgeries. ${ }^{[8,9]}$ Alverez et al. ${ }^{[7]}$ reported that postoperative pulmonary and cardiovascular complications were frequently encountered in the elderly, and consequently, the duration of hospital stay was prolonged in such patients. Martínez-Serrano et al. ${ }^{[6]}$ stated that advanced age was an effective factor on morbidity and mortality in incarcerated AWH cases. Likewise, in the present study, it was demonstrated that advanced age had a significant effect on morbidity $(\mathrm{p}<0.001)$ and mortality $(\mathrm{p}<0.005)$. Of the patients with morbidity, $85.2 \%$ were $\geq 65$ years, whereas all patients with mortality were $\geq 65$ years.

High ASA score (III-IV) and concomitant diseases are the other factors that affect mortality and morbidity. ${ }^{[7]}$ Gloub et al. ${ }^{[10]}$ reported that high ASA score was one of the most important independent risk factors affecting mortality. A significantly longer hospital stay and a significantly higher morbidity rate have also been reported in elderly patients with ASA class III or IV who underwent emergency hernia repair. ${ }^{[4]}$ The study conducted by Alvarez et al. ${ }^{[7]}$ reported that high ASA score was a factor affecting morbidity and mortality. The present study demonstrated that patients with high ASA score had significant morbidity $(\mathrm{p}<0.001)$ and mortality $(\mathrm{p}=0.029)$.

Late presentation to the hospital is also an important factor for morbidity and mortality since it is likely to form a basis for intestinal necrosis and resection. Ashirov et al. ${ }^{[1]}$ stated that the mortality was high among the femoral hernia cases presenting to the hospital later than 48 hours. Kulah et al..$^{[4]}$ demonstrated that morbidity and mortality rates were increased due to strangulation and necrosis in incarcerated hernia cases presenting to the hospital later as compared to those presenting earlier. Patients presenting to the hospital 24 hours after the development of incarceration accounted for $81.8 \%$ of the cases who died. In the present study, $83.3 \%$ of the cases who died and $77.8 \%$ of the cases with morbidity were the patients who presented to the hospital 24 hours after the development of incarceration. Late presentation to the hospital was attributed to the socioeconomic status of the patient, to presentation to small hospitals that lack a relevant specialist, and to misdiagnosis by the physicians. The present study also demonstrated that late presentation to the hospital had a significant effect on morbidity and mortality $(\mathrm{p}<0.001$ and $\mathrm{p}=0.026$, respectively).

General anesthesia has been reported to be one of the factors affecting mortality due to the presence of concomitant disease. ${ }^{[4,7]}$ Derici et al. ${ }^{[5]}$ reported that the type of anesthesia had no effect on mortality, but general anesthesia significantly increased the morbidity as compared to spinal anesthesia. The present study demonstrated that general anesthesia increased the morbidity as compared to spinal anesthesia $(\mathrm{p}=0.017)$, but had no significant effect on mortality $(\mathrm{p}=1.00)$.

Strangulation of a hernia is a surgical emergency and has high mortality. Mortality increases in case there is a need for intestinal resection. ${ }^{[12]}$ Femoral type hernia substantially leads to incarceration and strangulation, and thus requires intestinal resection. ${ }^{[13,14]}$ Among the hernia types, intestinal necrosis is most commonly encountered in femoral hernias. However, no significant effect of the hernia type on mortality and morbidity has been demonstrated ${ }^{[4,15]}$ Femoral hernia may be misdiagnosed as inguinal hernia, lymphadenopathy, lipoma, or psoas abscess. ${ }^{[16]}$ The rate of incarceration and strangulation has been reported to be $44 \%-86 \%$ in femoral hernias. ${ }^{[8,17]}$ In the present study, the rates of strangulation and necrosis in femoral hernias were found as $87.5 \%$ and $62.5 \%$, respectively.

In the study conducted by Kurt et al., ${ }^{[3]}$ intestinal necrosis was most common in femoral hernia cases. In the present study, the rate of necrosis was found significantly higher in femoral hernia cases as compared to the other types of hernia.

In the present study, while strangulation was found to have a significant effect on morbidity $(p=0.001)$, it had no significant effect on mortality $(\mathrm{p}=0.433)$. However, it was observed that necrosis had a significant effect on both morbidity $(\mathrm{p}=0.001)$ and mortality $(\mathrm{p}=0.014)$.

The duration of hospital stay increases due to necrosis and resection. Kurt et al..$^{[3]}$ reported that the period after the resection due to necrosis was effective on morbidity and prolonged the duration of hospital stay. In the present study, the duration of hospital stay was found to be prolonged in the patients undergoing resection due to necrosis $(\mathrm{p}=0.001)$. Necrosis was lowest in inguinal hernia cases, and the time to discharge was shorter as compared to the other hernia types $(\mathrm{p}<0.001)$.

The gold standard in the surgical treatment of incarcerated AWHs is repair of the hernia with low morbidity and mortality and low recurrence rate in the long-term follow-up. Factors that influence recurrences in hernia surgery include inadequate surgical technique, size of the hernia, obesity, wound site infection, cigarette smoking, diabetes, COPD, advanced age, and the use of steroid. ${ }^{[18-22]}$ Recurrence rate has been reported in the literature as $1-22 \%$ for incarcerated inguinal hernias ${ }^{[23,24]}$ and as $1-10 \%$ for incarcerated femoral hernias. ${ }^{[25]}$ In the present study, recurrence was determined in totally $8(4.2 \%)$ cases; the recurrence rate was highest in inguinal hernia $(n=6,5.9 \%)$ 
as compared to all hernia types.

Synthetic grafts have been used in hernia surgery for 30 years. The polypropylene graft is durable and stimulates fibroplasia due to its monofilament structure. It neither triggers infection nor is rejected by the tissues. ${ }^{[26,27]}$ Mesh use has no contraindication in many patients that require intestinal resection. It has been reported that polypropylene meshes can be used safely in inguinal hernia cases that undergo intestinal resection. ${ }^{[28]}$ Polypropylene meshes are resistant against infections due to their macroporous structure and can be used safely in AWH defects. Repair techniques performed using Prolene mesh in anterior AWHs in the hands of experienced surgeons and in accordance with the technique would provide lower morbidity and recurrence rates. In their study, Beltran et al. ${ }^{[29]}$ used mesh in both elective and strangulated hernia repairs and could not find any significant difference in terms of postoperative complications. Bessa et al. ${ }^{[30]}$ stated that there was no difference between elective or emergency mesh use in terms of postoperative complications and that mesh could be used safely. Papaziogas et al. ${ }^{[31]}$ found no difference between inguinal hernia repair with and without mesh in terms of postoperative complications and wound infection. Surgical repair using mesh is the current trend in the treatment of primary or recurrent umbilical hernias in both obese and non-obese adults due to its lower recurrence rate as compared to surgical repair by suturing $(1 \%$ vs. $11 \%)$. $^{[32,33]}$

In conclusion, the present study demonstrated that advanced age ( $\geq 65$ years), presence of concomitant disease, intestinal strangulation, necrosis and intestinal resection, high ASA score (III-IV), and time from onset of the symptoms were effective on morbidity and mortality. General anesthesia poses a risk for morbidity as well. As AWH is identified, surgery should be performed under elective conditions in order to avoid the risks of emergency surgery.

\section{REFERENCES}

1. Fitzgibbons Jr. RJ, Cemaj S, Quinn TH. Abdominal wall hernias. In: Mulholland MW, Doherty GM, Lillemoe KD, Maier RV, Simeone D, Upchurch GR, editors. Greenfields surgery. Scientific principles \& practice. 5th ed. Philadelphia, PA: Lippincott Williams and Wilkins; 2011. p. 1159-98.

2. Kulah B, Kulacoglu IH, Oruc MT, Duzgun AP, Moran M, Ozmen MM, et al. Presentation and outcome of incarcerated external hernias in adults. Am J Surg 2001;181:101-4.

3. Kurt N, Oncel M, Ozkan Z, Bingul S. Risk and outcome of bowel resection in patients with incarcerated groin hernias: retrospective study. World J Surg 2003;27:741-3.

4. Kulah B, Duzgun AP, Moran M, Kulacoglu IH, Ozmen MM, Coskun F. Emergency hernia repairs in elderly patients. Am J Surg 2001; 182:455-9.

5. Derici H, Unalp HR, Bozdag AD, Nazli O, Tansug T, Kamer E. Factors affecting morbidity and mortality in incarcerated abdominal wall hernias. Hernia 2007;11:341-6.
6. Martínez-Serrano MA, Pereira JA, Sancho JJ, López-Cano M, Bombuy E, Hidalgo J; Study Group of Abdominal Hernia Surgery of the Catalan Society of Surgery. Risk of death after emergency repair of abdominal wall hernias. Still waiting for improvement. Langenbecks Arch Surg 2010;395:551-6.

7. Alvarez JA, Baldonedo RF, Bear IG, Solís JA, Alvarez P, Jorge JI. Incarcerated groin hernias in adults: presentation and outcome. Hernia 2004;8:121-6.

8. Oishi SN, Page CP, Schwesinger WH. Complicated presentations of groin hernias. Am J Surg 1991;162:568-71.

9. Heydorn WH, Velanovich V. A five-year U.S. Army experience with 36,250 abdominal hernia repairs. Am Surg 1990;56:596-600.

10. Golub R, Cantu R. Incarcerated anterior abdominal wall hernias in a community hospital. Hernia 1998;2:157-61.

11. Ashirov AA, Malevannyı̆ AV. Immediate results of treating strangulated hernias. [Article in Russian] Vestn Khir Im I I Grek 1986;136:37-41. [Abstract]

12. Tiernan JP, Katsarelis H, Garner JP, Skinner PP. Excellent outcomes after emergency groin hernia repair. Hernia 2010;14:485-8.

13. Gallegos NC, Dawson J, Jarvis M, Hobsley M. Risk of strangulation in groin hernias. Br J Surg 1991;78:1171-3.

14. Ihedioha U, Alani A, Modak P, Chong P, O’Dwyer PJ. Hernias are the most common cause of strangulation in patients presenting with small bowel obstruction. Hernia 2006;10:338-40.

15. Nesterenko IuA, Shovskiǔ OL. Outcome of treatment of incarcerated hernia. [Article in Russian] Khirurgiia (Mosk) 1993:26-30. [Abstract]

16. Alimoglu O, Kaya B, Okan I, Dasiran F, Guzey D, Bas G, et al. Femoral hernia: a review of 83 cases. Hernia 2006;10:703.

17. Hachisuka T. Femoral hernia repair. Surg Clin North Am 2003;83:1189-205.

18. Venclauskas L, Maleckas A, Kiudelis M. One-year followup after incisional hernia treatment: results of a prospective randomized study. Hernia 2010;14:575-82.

19. Burger JW, Luijendijk RW, Hop WC, Halm JA, Verdaasdonk EG, Jeekel J. Long-term follow-up of a randomized controlled trial of suture versus mesh repair of incisional hernia. Ann Surg 2004;240:578-85.

20. Luijendijk RW, Hop WC, van den Tol MP, de Lange DC, Braaksma MM, IJzermans JN, et al. A comparison of suture repair with mesh repair for incisional hernia. N Engl J Med 2000;343:392-8.

21. Le H, Bender JS. Retrofascial mesh repair of ventral incisional hernias. Am J Surg 2005;189:373-5.

22. Iqbal CW, Pham TH, Joseph A, Mai J, Thompson GB, Sarr MG. Long-term outcome of 254 complex incisional hernia repairs using the modified Rives-Stoppa technique. World J Surg 2007;31:2398-404.

23. Derici H, Unalp HR, Nazli O, Kamer E, Coskun M, Tansug T, et al. Prosthetic repair of incarcerated inguinal hernias: is it a reliable method? Langenbecks Arch Surg 2010;395:575-9.

24. Haapaniemi S, Nilsson E. Recurrence and pain three years after groin hernia repair. Validation of postal questionnaire and selective physical examination as a method of follow-up. Eur J Surg 2002;168:22-8.

25. Naude GP, Ocon S, Bongard F. Femoral hernia: the dire consequences of a missed diagnosis. Am J Emerg Med 1997;15:680-2.

26. Hetzer FH, Hotz T, Steinke W, Schlumpf R, Decurtins M, 
Largiader F. Gold standard for inguinal hernia repair: Shouldice or Lichtenstein? Hernia 1999;3:117-20.

27. Lichtenstein IL, Shulman AG, Amid PK, Montllor MM. The tension-free hernioplasty. Am J Surg 1989;157:188-93.

28. Wysocki A, Kulawik J, Poźniczek M, Strzałka M. Is the Lichtenstein operation of strangulated groin hernia a safe procedure? World J Surg 2006;30:2065-70.

29. Beltrán MA, Cruces KS. Are the outcomes of emergency Lichtenstein hernioplasty similar to the outcomes of elective Lichtenstein hernioplasty? Int J Surg 2007;5:198-204.

30. Bessa SS, Katri KM, Abdel-Salam WN, Abdel-Baki NA. Early results from the use of the Lichtenstein repair in the man- agement of strangulated groin hernia. Hernia 2007;11:23942.

31. Papaziogas B, Lazaridis Ch, Makris J, Koutelidakis J, Patsas A, Grigoriou M, et al. Tension-free repair versus modified Bassini technique (Andrews technique) for strangulated inguinal hernia: a comparative study. Hernia 2005;9:156-9.

32. Arroyo A, García P, Pérez F, Andreu J, Candela F, Calpena R. Randomized clinical trial comparing suture and mesh repair of umbilical hernia in adults. Br J Surg 2001;88:1321-3.

33. Sanjay P, Reid TD, Davies EL, Arumugam PJ, Woodward A. Retrospective comparison of mesh and sutured repair for adult umbilical hernias. Hernia 2005;9:248-51. 